\title{
1. Innovation in competition law analysis: making sense of on-going academic and policy debates
}

\section{Pieter Van Cleynenbreugel}

\section{INTRODUCTION}

Although it is widely believed that market economies characterised by undistorted competition contribute directly to innovation, ${ }^{1}$ the relationship between innovation and competition law remains mysterious. As a result, scholars have grappled with the notion of innovation and its place within the competition law analytical framework. Analyses have varied between claims that no place should be awarded to innovation in competition law analysis ${ }^{2}$ and proposals to develop or fine-tune new economic tests grounded directly in innovation-related arguments. ${ }^{3}$ In the same way, competition authorities seem to have either excluded different innovation-related testing frameworks or have - often cautiously proposed a more innovation-focused analytical framework or theory of competitive harm.

Confronted with that variety of approaches in covering the relationship between innovation and competition law analysis, one may be inclined to find it difficult to distinguish the forest from the trees throughout those debates. In an attempt at making sense of the different takes on the relationship between competition law analysis and innovation, this brief

1 See in general, G. M. Peter Swann, The Economics of Innovation. An introduction (Edward Elgar Publishing, Cheltenham, 2009), 8-20.

2 Pablo Ibanez Colomo, 'Restrictions on innovation in EU competition law', European Law Review (2016) 41 (2), 201-219.

3 Nicolas Petit, 'Innovation Competition, Unilateral Effects and Merger Control Policy', working paper available at https://papers.ssrn.com/sol3/papers. cfm?abstract_id=3113077; Thibault Schrepel, 'Predatory Innovation: The Definite Need for Legal Recognition', available at https://papers.ssrn.com/sol3/papers. cfm?abstract_id=2997586. 
introductory chapter undertakes to offer a framework categorising the different competition law and innovation approaches into four different yet complementary analytical boxes, prior to categorising the different chapters in this volume into one of those boxes. In order to develop this framework, section 2 of this chapter briefly restates the basics derived from economic analysis that determine or could determine roles granted to innovation in competition law analysis. Section 3 actually distinguishes four different approaches towards competition law and innovation, proposing a table composed of four different yet complementary analytical boxes able to capture those varieties in scholarship. Building upon that analysis, section 4 categorises the different chapters in this volume within one of the four identified competition law and innovation boxes.

It should be clear at the outset that the purpose of this chapter is not to propose a way forward in competition law and innovation analysis. It rather aims to offer a brief overview of different scholarly approaches linking innovation to competition law in order better to frame, understand and compare the roles of innovation in competition law analysis and the contributions the different chapters included in this volume make to that analysis. As such, the chapter is above all to be read as an introduction to both the body of scholarship dedicated to competition law and its relationship to innovation in general and to the different and varied chapters included in this volume.

\section{INNOVATION, COMPETITIVE MARKETS AND COMPETITION LAW: BETWEEN SCHUMPETER AND ARROW}

Innovation in and of itself remains an open-ended notion. In essence, it encompasses the commercialisation of newly invented or upgraded products (product innovation) or production and distribution processes (process innovation). Such innovation can take place in a most disruptive way, creating an entirely new market for a new product or can be rather incremental, changing the dynamics on an existing market. ${ }^{4}$ What is clear, however, is that no matter what definition of innovation one adheres to, it has the potential to shake up markets or to at least change

4 See European Commission, Competition policy brief, EU merger control and innovation, April 2016, available at http://ec.europa.eu/competition/ publications/cpb/2016/2016_001_en.pdf, p. 2. 
the competitive dynamics within those markets. The relationship between competitive markets and innovation has therefore been the subject of vigorous debate among economists. In that particular context, discussions on the relationship between competitive markets and innovation almost always also start from the contrast between so-called Schumpeterian and Arrowian approaches towards innovation in competitive markets.

According to the teachings of Joseph Schumpeter, product innovation is guaranteed best by less competition than more..$^{5}$ In line with his ideas on creative destruction and the replacement of old products with completely new ones at some point in time, Schumpeter argues that less competition provides more incentives to a business to engage in product innovation, as the incumbent business may be afraid that its products will be replaced by a newer and better product that would result in the creation of a new market and the destruction of the old product market. As the European Commission summarised Schumpeter's thoughts in 2016:

Less competition increases the post-innovation rewards for the innovator, which in turn will increase the incentives to engage in research and development (R\&D). Even if there is little price competition in the market, innovation competition from firms seeking to take over the leading supplier's role (competition for the market) will goad the current market leader to invest in innovation to stay ahead, or else lose its market position to rivals. ${ }^{6}$

Product competition, or at least the risk of it, stimulates innovation in that understanding.

Kenneth Arrow, on the other hand, argues that vigorous price competition rather than product competition serves as a means to stimulate innovation. In his opinion, the more pressure businesses feel with regard to their pricing decisions because of competitors also trying to capture demand, the more incentives to innovate will remain with the businesses concerned. ${ }^{7}$ Again according to the European Commission:

In a competitive environment, a newly invented product will not cannibalise the firm's own profit as much as it would under a less competitive market structure. In a competitive market, an invention will allow the inventor to gain

5 Joseph A. Schumpeter, Capitalism, Socialism and Democracy (Routledge, Abingdon, 2010), 82-83.

6 European Commission, n. 4, p. 1 (emphasis in original).

7 Kenneth Arrow, 'Economic Welfare and the Allocation of Resources for Invention', RAND Paper 1959, available at https://www.rand.org/pubs/papers/ P1856.html, pp. 15-20. 
sales from competitors and will therefore be applied to a higher output. Innovation incentives depend not on post-innovation profits per se but on the difference between post-innovation and pre-innovation rents. For these reasons, less competition in the market would reduce the incentives to innovate. ${ }^{8}$

As such, the threat of competition in itself incentivises businesses to engage in more innovative practices, both in terms of disruptive or incremental product innovation and in terms of less intensive process innovation, in which new production or distribution processes are commercialised.

Both approaches towards competitive markets and innovation are not mutually exclusive, as economist Carl Shapiro has demonstrated. ${ }^{9}$ Indeed, both Schumpeter and Arrow essentially agree on the fact that markets need to be contestable, meaning that they need to enable new entrants to gain market access and to use that market access to contest incumbent businesses. In addition, in order to stimulate innovation, synergies between complementary products or services have to be recognised and realised, as bringing together such synergetic products may increase the likeliness of innovations to take shape in the future. ${ }^{10}$ Competition law plays a key role in that regard, as it offers tools to take action against market foreclosure and the competitive harm resulting directly or indirectly therefrom and to justify synergies that complementary products or services can bring in an attempt to stimulate innovation. At the same time, both positions also agree that businesses need to be able to capture the value of their innovation and to benefit from the competitive advantage obtained from their innovative actions. They have to be able to appropriate the value of their innovation. ${ }^{11}$ To do so, the recognition of certain types of intellectual property rights protection and ways to keep relying on their innovations are to be stimulated in that regard. Again, competition law can play a clear role in allowing such rights to be recognised and exercised within a framework also favouring undistorted competition.

8 European Commission, n. 4, p. 2 (emphasis in original).

9 Carl Shapiro, 'Competition and Innovation. Did Arrow Hit the Bull's Eye?', in Josh Lerner and Scott Stern, The Rate and Direction of Inventive Activity Revisited (NBER 2012), 361-410.

10 European Commission, n. 4, p. 2.

11 See in a particular context, Dirk Auer, 'Appropriability and the European Commission's Android Investigation', Columbia Journal of European Law (2017) 23, 647-680. 
It is clear from the foregoing basic overview that innovation as such can benefit from a competition law framework that ensures the contestability of markets, acknowledges the potential to appropriate certain benefits and stimulates synergies between complementary products. In that understanding, competition law serves above all as an instrument to enable and facilitate innovation in markets, either at the level of individual products or at the level of competitive markets as a whole. At the same time, competition law should serve as an instrument to act against innovations that have as a consequence the foreclosure - and diminished contestability - of markets or the abuse of appropriation tools acknowledged by law. On a whole, competition law should thus be considered an instrument making possible innovation competition both in specific product markets and beyond.

\section{DEFINING THE ROLES OF INNOVATION IN COMPETITION LAW ANALYSIS: A FRAMEWORK}

It follows from the previous section that competition law can serve as a tool to allow for innovations to take place and as a means to protect against certain excesses of innovation. Although it is clear that competition law can play a role in the innovative process, a question that has not been answered in economic studies concerns the extent to which competition law should or could incorporate directly or indirectly innovation-structured arguments into its analytical framework. In essence, competition law targets certain practices that harm undistorted competition. As such, it operates on the basis of a 'theory of harm' that allows enforcement authorities and businesses to have some kind of certainty as to what practices are considered anticompetitive and what practices can be justified by virtue of offsetting procompetitive or efficiency-oriented items. Although competition law scholarship has largely centred on such theories of harm and has related them to innovation arguments, no singularly clear picture emerges from an even superficial survey of the practices and writings of competition authorities and scholars working in the field. At a general level of competition law and innovation scholarship, studies on the relationship between innovation and competition law focus on whether innovation-related arguments could be integrated in those theories of harm. Two different positions can be distinguished in that respect, differentiating the extent to which innovation-related concerns are to be included directly or indirectly in the applicable theory of harm underlying the application of competition law in a given jurisdiction. 
A first group of policy and scholarship documents suggests that innovation remains a value exogenous or external to competition law. Competition law focuses on market behaviour and the structure of the market and innovation can be considered a consequence directly flowing from that structure. At the same time, innovation as such is not a value directly protected by competition law itself. As such, protection or enabling of innovation cannot be invoked as a justification to otherwise anticompetitive types of behaviour or as a way to determine the presence or not of a restriction on competition. To the extent that innovation is considered as an exogenous value to competition, one may either consider innovation as a positive value, worthy of protection under competition law, or as a negative value, bringing new problems and issues that require remedial action within the scope of competition law.

- An example of the first tendency would seem to be the European Commission's willingness to refer to the impact of anticompetitive behaviour on innovation as an illustration of competitive harm caused by such behaviour. ${ }^{12}$ In doing so, the European Commission does not consider innovation to be the only or even key core value requiring protection, but rather a policy value that could be at stake in a supplementary way when defining or condemning anticompetitive practices. ${ }^{13}$ As such, innovation is a value that deserves protection and that is considered as a positive thing to happen in a market environment. At the same time, however, such innovation does not need to be part of the analytical framework of competition law in itself. The mere presence of a limit on the ability of businesses to compete is considered also to have repercussions on the ability of undertakings to innovate. From that point of view, protecting competition indirectly also means protecting innovation. At the same time, however, the competition law framework does not in itself incorporate innovation-related arguments directly into the assessment of anticompetitive behaviour.

- In a similar fashion, competition law is also confronted with innovation as a negative exogenous value requiring to be addressed partially through competition law. The emergence of big data is a key example of this tendency. Big data result in the ability of certain businesses to collect, use and determine pricing decisions

12 See Communication from the Commission - Guidelines on the applicability of Article 101 of the Treaty on the Functioning of the European Union to horizontal co-operation agreements [2011] OJ C11/1, para. 27.

13 See for that argument, Colomo, n. 2. 
beyond what was previously possible or feasible. Doing so may result in anticompetitive behaviour being facilitated or in certain businesses being deprived of opportunities because of unwillingness of data holders to share certain kinds of information. To overcome those challenges, one often sees a tendency to adopt specific regulatory instruments that determine, more or less explicitly, their relationship to competition law. The emergence of EU data protection regulation and the multitude of reflections on how this regulation relates to competition law demonstrate to what extent this is the case. ${ }^{14}$ In that understanding, innovation in data collection and retention technologies triggers potential competition law concerns, which have to be addressed. From that point of view, studies question the roles competition law can play in addition to or as a substitute for specific instruments of regulation in innovative industries.

A second line of policy and scholarship starts from the opposite position. Given that innovation is an aim to be reached through competitive markets, nothing would seem to impede that innovation as a value could be invoked as a policy value to justify certain types of behaviour or to determine the restrictive nature of certain types of behaviour. In that understanding, behaviour enabling or limiting that policy value could be approved or prohibited on the basis of competition law. From that point of view, innovation would become a value endogenous or internal to competition law, requiring authorities to take innovation arguments into account directly into their competition law analysis.

- In this framework, innovation can again be considered a positive value to be protected. Within that understanding, competition law analysis should incorporate specific attention to innovation as a value worthy of protection under competition law. In the field of merger control, one witnesses a tendency to that extent in both US and EU law. The impact mergers have on research and development investment in a given product ${ }^{15}$ or even on the overall existence or

14 Inge Graef, EU Competition Law, Data Protection and Online Platforms: Data as Essential Facility (Kluwer, The Hague, 2016).

15 See Justus Haucap and Joel Stiebale, 'How Mergers Affect Innovation: Theory and Evidence from the Pharmaceutical Industry', Discussion Paper No. 218, Düsseldorf Institute of Competition Economics, April 2016, available at http://www.dice.hhu.de/fileadmin/redaktion/Fakultaeten/Wirtschaftswissenschaft liche_Fakultaet/DICE/Discussion_Paper/218_Haucap_Stiebale.pdf. 
development of innovation markets ${ }^{16}$ has seeped through explicitly in scholarly analyses of this kind. At the EU level, the introduction of a significant impediment to innovation competition test has been identified - and criticised - in this context. ${ }^{17}$ Scholarly studies identifying this kind of direct innovation relationship do not always agree with this stance. They generally explore whether and to what extent such tests would be compatible with the legal framework in place and ask whether modifications to that framework are considered necessary in that respect.

- In the same vein, the excesses or negative effects on competition of innovation or innovative technologies have also been recognised. In those settings, the question has arisen as to whether certain innovations, which facilitate abusive or other anticompetitive action, should be recognised specifically as such, in order to avoid the difficulties of having to classify them under more traditional banners of competition law. From that point of view, the introduction of a specific predatory innovation abuse has been proposed, as have other elements of anticompetitive innovative behaviour. ${ }^{18}$

The overall picture that emerges, therefore, is one of a diversity of approaches and studies, each proposing either an exogenous or an endogenous take on the competition law and innovation relationship. Within those studies, a difference is made between whether innovation is seen as a negative value or as a positive value. It deserves to be clarified in that respect that scholars having a positive or negative take on innovation do not necessarily and generally consider all kinds of innovation negative or positive. Instead, they generally propose an analytical framework to deal with particular instances of innovation that have been valued either positively or negatively. From that point of view, they reflect on the law is it is and as it could be when taking innovation evolutions or threats seriously.

The following scheme summarises the different elements identified in competition law scholarship. From that perspective, a table with four quadrants structured along the exogenous-endogenous attributes and positive-negative values can be identified (Table 1.1). In each of the

16 See Markus Glader, Innovation Markets and Competition Analysis. EU Competition Law and US Antitrust Law (Edward Elgar Publishing, Cheltenham, 2016).

17 Petit, n. 3.

18 Schrepel, n. 3. 
quadrants, I have added, by ways of example, an illustration of scholarship or competition law arguments made reflecting how innovation as a value is perceived throughout and integrated in competition law analysis.

Table 1.1 Proposed innovation and competition law analytical matrix

\begin{tabular}{lll}
\hline Innovation as a value & $\begin{array}{l}\text { Exogenous to competition } \\
\text { law analysis }\end{array}$ & $\begin{array}{l}\text { Endogenous to } \\
\text { competition law analysis }\end{array}$ \\
\hline Positive value & $\begin{array}{l}\text { European Commission } \\
\text { Article 101/102 TFEU } \\
\text { analysis currently in place } \\
\text { (Data protection) }\end{array}$ & $\begin{array}{l}\text { Mergers and innovation - } \\
\text { new economic and legal } \\
\text { tests }\end{array}$ \\
$\begin{array}{l}\text { Regulation and } \\
\text { competition scholarship }\end{array}$ & $\begin{array}{l}\text { Predatory innovation } \\
\text { proposals }\end{array}$ \\
\hline
\end{tabular}

The diversity in policy and scholarly approaches thus identified attests to a variety of research perspectives in the relationship between competition law and innovation. It goes without saying that there is no one right approach to tackling the relationship and that it falls upon responsible policymakers to think through the implications of that relationship in all its varieties. The endogenous-exogenous and positive-negative distinctions nevertheless help at classifying research and at structuring debates regarding competition law and innovation into subcategories allowing for a more informed debate in each of those subcategories. Without necessarily proposing a single way forward, studies in each of the quadrants offer food for thought for policymakers grappling with innovative industries and thinking about using competition law as an instrument to structure, enable or restrain innovative developments in certain situations.

\section{FRAMING THE OTHER CHAPTERS OF THIS BOOK WITHIN THE PROPOSED FRAMEWORK}

The chapters in this volume can each be categorised in one of the four quadrants distinguished in Table 1.1. Although the book is not structured according to those quadrants, it may be helpful to understand the scope of the different arguments by relating the chapters to those quadrants. Doing so enables better understanding of where and how the arguments made throughout this book intersect, differ or can be considered as complementing each other.

It is interesting to note at the outset that none of the chapters included in this volume considers innovation to be a negative value to be 
addressed directly by competition law. On the contrary, all authors consider innovation to be a positive value worthy of protection. As a result, none of the chapters falls within the endogenous-negative quadrant of Table 1.1.

Different authors have nevertheless sought to identify the possibilities of considering innovation as an endogenous positive value worthy of competition law protection. Within that framework, they have looked at whether competition law could grant 'innovation as a positive value' a direct place in its analytical framework. The chapters by John Kwoka, Francisco Marcos and Juha Vesala - all in Part I of this volume particularly engage in this analysis. In the same way, the chapters by Björn Lundqvist and Severin Frank and Wolfgang Kerber in Part III raise similar questions to that extent.

To say that the other authors of this volume have a normative preference for keeping innovation-based arguments out of traditional competition law analysis would be an overstatement. What one can nevertheless infer from their chapters is that they do not directly target innovation as an endogenous value that competition law does or should protect in this context. They rather see innovation as an exogenous value being affected potentially by anticompetitive behaviour and therefore worthy of protection through the existing tools and frameworks characteristic of competition law. In that respect, the authors of the chapters in Part II of the volume - Nicolo Zingales, Claudia Seitz and Shuya Hayashi, Kunlin Wu and Benjawan Tangsatapornpan - particularly consider innovation to generate potentially negative consequences, which competition law could serve to address. The same reflection is made by Daniel Zimmer in Chapter 12 on challenges of competition law in the digital economy.

In the same way, other authors view innovation as a positive value exogenous to competition law analysis. Nevertheless, the classical tools and instruments of competition law analysis (market definition, analysis of market foreclosure, economic efficiencies and the particular enforcement system in place) could be relied on to contribute - albeit indirectly - to innovation-oriented markets. From that perspective, the chapters by Viktoria Robertson and Marco Botta, Mariateresa Maggiolino and Maria Lillà Montagnani, Petri Kuoppamäki and Simonetta Vezzoso analyse the ways in which the existing legal framework deals with innovation-related arguments, without necessarily proposing the integration of innovation in the existing analytical framework of competition law.

The variety of perspectives on the competition law and innovation relationship present in the following chapters thus give an overall picture of the current and ongoing debates in competition law and innovation 
scholarship. At the same time, the chapters often make important new contributions to one of the quadrants identified in this chapter, showing that debates on the relationship between competition law and innovation analysis are still in full swing and continue to benefit from new insights along the way. It is hoped that the chapters in this volume contribute to further stimulating academic debate and policy actions in this domain. 